\title{
Towards a functional phytosociology: the functional ecology of woody diagnostic species and their vegetation classes in Northern Italy
}

\author{
Magda Zanzottera ${ }^{(1-2)}$, \\ Michele Dalle Fratte ${ }^{(1)}$, \\ Marco Caccianiga ${ }^{(2)}$, \\ Simon Pierce ${ }^{(3)}$, \\ Bruno Enrico Leone Cerabolini ${ }^{(1)}$
}

\begin{abstract}
Vegetation is often classified through phytosociology, which defines floristically and ecologically coherent units identified by diagnostic species. Since species- and community-environment relations are regulated by plant functional traits, it is likely that phytosociology has a strong functional underpinning, although the past and current phytosociology does not explicitly tackle this issue. Here we provide an analysis of functional traits of 221 woody species from Northern Italy, diagnostic of 21 European woody vegetation classes (including alien dominated ones). We assessed whether the functional space occupied by selected species corresponds to the physiognomy and ecology of the vegetation they represent, and whether this could help to evaluate major threats, such as invasion by alien species. For each species we collected from Authors' datasets leaf trait data (leaf area, specific leaf area, leaf dry matter content, carbon to nitrogen ratio, leaf nitrogen content) and whole plant (plant height, seed mass) traits, and calculated Competitor, Stress-tolerant, Ruderal (CSR) scores. We identified the multidimensional functional trait space of diagnostic species and clustered classes according to their scores in the functional space, to check whether their physiognomy was coherently represented and mirrored in the CSR space. Lastly, we tested for differences between native and neophyte species and their overlap with classes. Diagnostic species mirrored the global spectrum of plant form and function, and classes showed a functional pattern coherent with their physiognomy and ecology. Evergreen dominated classes showed a similar convergence toward conservative characteristics and the stress-tolerant strategy, as opposed to deciduous forest classes that showed a tendency toward the competitive strategy. None of the classes showed a marked ruderal strategy, thus abiotic stress and biotic competition are the main ecological drivers affecting woody vegetation. Neophyte woody species exhibited relatively more competitive strategies compared to natives, and their invasion could be facilitated in resource-limited or mildly disturbed environments, should climate warming or increased nutrient availability occur. We demonstrated that plant traits and CSR strategies of woody diagnostic species reliably indicate the structure and functions of the phytosociological classes they represent, opening the way to the development of a "functional phytosociology".
\end{abstract}

Keywords: CSR Adaptive Strategies, Forests, Shrublands, Global Spectrum, Neophytes, Plant Functional Traits, Structure and Functions, Typical Species.

\section{Introduction}

Phytosociology proposed one of the most well-known and widely applied floristic approaches to vegetation classification, i.e., syntaxonomy, which categorizes vegetation into floristically coherent units called syntaxa by the analysis of lists of species recorded in vegetation plots (Becking 1957). Of particular relevance is the use of diagnostic species that occur in a single vegetation unit (character species) or in a few vegetation units (differential species), and that indicate a specific syntaxon, separating it from all others (Chytry et al. 2002). Diagnostic species can be statistically determined by measuring "fidelity", a measure of species concentration in a given vegetation unit, and their corresponding scarcity or absence in other units; species exceeding a fidelity threshold are considered diagnostic (Chytry et al. 2002). Syn- taxa are included in a floristically defined hierarchical classification system based on the presence of common groups of diagnostic species that allow the identification of higher hierarchical levels, and each rank level is characterized by its own set of diagnostic species (Braun-Blanquet 1932). The highest rank is the "class", which is associated to a given biogeographic context and carries ecological information (Pignatti et al. 1995).

Generally, phytosociology recognizes the relationships between plant communities and environmental factors (Braun-Blanquet 1932), as its principal goal is the definition of vegetation types by their floristic composition in relation to given ecological contexts. Since the study of species- and community-environment relations is key to the functional interpretation of plant communities, concepts related to vegetation 
functionality should be implicitly included in phytosociology, but they remain scarcely investigated. Functional ecology organizes species according to their adaptive traits, both by spectra of trait variability and by delimiting functionally homogeneous groups, i.e., functional types, defined as "sets of species showing similar responses to the environment and similar effects on ecosystem functioning" (Smith et al. 1992). These groups reflect plant assemblages responding coherently to abiotic and biotic environmental factors. A trait-based approach is known to provide predictive and quantitative insights into the general mechanisms of plant communities and ecosystem functioning, in contrast to descriptive approaches based on species identity only (Díaz \& Cabido 2001).

The adoption of functional traits has made it possible to define the functional spaces occupied by species, such as the global spectrum of plant form and function (Díaz et al. 2016). This demonstrates that the trade-offs between six key traits of vascular plants (linked to survival, growth and reproduction) are determined by two main axes of adaptation: the size of plants and their parts, and resource economics (i.e., resource acquisition vs. conservation, or "leaf economics" - Wright et al. 2004). Another space related to plant functioning is that defined by CSR plant strategies (Competitive, Stress tolerant, Ruderal - Grime 2001) where species are arranged along axes based on trait values reflecting their response to the main ecological drivers underlying vegetation processes, such as competition, stress and disturbance (Grime 2001, Grime \& Pierce 2012). While these constraints describe species adaptations and strategies, many studies have analyzed community-level trait composition (Garnier et al. 2016) which is necessary to gain further insight into environmental drivers. Bruelheide et al. (2018) have also recently defined the functional space of plant communities at the global scale, starting from plot-level trait composition. Nonetheless, functional analyses of plant communities as identified by syntaxonomy have been attempted only using syntaxonomic unit lower than the rank of class, such as associations (Poldini et al. 2011, Zanzottera et al. 2020) and orders (Macedo et al. 2010), whereas at higher ranks the functional connotation of syntaxa has rarely been generally assessed (Macedo et al. 2010).

Crucially, the distribution of functional traits in high rank plant assemblages (i.e., classes) of woody vegetation could provide an improved characterization of the role of phytosociology in European policies dedicated to the conservation of biodiversity, such as Natura 2000 habitat types (Habitats Directive, 92/43/EEC), as well as to sustainable forest management (Blasi \& Burrascano 2013). Many syntaxa allows the identification of habitat types listed in Annex 1 of the Habitats Directive (Rodwell et al. 2018), hence a proper understanding of trait coordination could also be helpful to refine the assessment of their conservation status and habitat mapping (Dalle Fratte et al. 2019b). Besides, there are some limitations of forest classifications based on syntaxonomy (EEA 2006), mainly because it does not reflect the characteristics of forest ecosystems that are primary determinants of the indicators used for sustainable management of European forest types (EFTs). In this view, a functional classification could link phytosociological classes of woody vegetation with EFTs, providing a step toward effective indicators of sustainable forest management (Barbati et al. 2014, Giannetti et al. 2018) also for Natura 2000 habitat types (Bonari et al. 2021).

Recent evidence suggests that the inclusion of a trait-based approach allows a more accurate identification of diagnostic species (Ricotta et al. 2020), and this in turn could improve the understanding of the key ecological processes and threats that shape different plant communities as defined by phytosociology, such as stress, disturbance (also derived from land use change), and competition (which can also be related to invasion by alien species). In particular, naturalized alien species nowadays are part of the real vegetation of Europe to the point that several alien-dominated syntaxa have been recognized ( $\mathrm{Vi}$ ciani et al. 2020), and they are often listed among diagnostic species of natural vegetation (Mucina et al. 2016). The spread of alien species are context-dependent, particularly within sensitive ecosystems, and the effectiveness of their impacts across habitats and regions is still little understood (Dick et al. 2017). Thus, it is necessary to understand the functional role of alien species in natural species assemblages and environments that are potentially prone to invasion. Clarifying the link between functional ecology and phytosociology could also be helpful in resolving this issue.

In this study, we analyzed resource economics and size plant traits, as well as Grime's CSR strategies of 221 woody diagnostic species representative of 21 European phytosociological classes of woody vegetation, including alien-dominated classes, ranging from low shrublands to forests, and from Mediterranean to BorealAlpine bioclimatic zones. We selected woody species because they best represent the physiognomy and structure of communities they characterize, thus the analysis of their functional traits trade-offs can be expected to clarify plant-environment interactions within the communities. Specifically, we aimed to evaluate: (i) whether the classes represented by the selected species are also differentiated in the functional spaces defined by the global spectrum of plant form and function (Díaz et al. 2016) and by Grime's CSR plant strategies, coherently with their structure and physiognomy; and (ii) whether the functional trade-offs among diagnostic species are directly indicative of the threat repre- sented by the invasion of alien species in woody vegetation.

\section{Materials and methods}

\section{Functional trait collection and dataset structure}

For this study we selected a sample of woody species diagnostic of 21 classes of European woody vegetation. We defined woody vegetation as communities dominated by woody life forms, including shrubland, scrub, woodland and forest formations (Van Der Maarel \& Franklin 2012). The species we selected $(n=221)$ represent a large sample of woody species of Northern Italy (Tab. 1), and thus constitute a national-level interpretation of European classes of woody vegetation. Species were sampled at 83 sites widespread mostly in Northern Italy (Fig. S1 in Supplementary material), covering an area of approximately $65,000 \mathrm{~km}^{2}$ from sea level to 2650 $\mathrm{m}$ a.s.l. and a wide range of climatic regimes, from a Mediterranean near the coastline to a continental in lowland areas and a cold oceanic alpine climate in the mountains. Substrates include both silicate and carbonate rocks of different origin (Tab. S1 in Supplementary material).

We assigned each species to one or more classes according to the lists of diagnostic species provided by the EuroVeg checklist (Mucina et al. 2016); the 21 classes we considered were those with at least five species for which functional traits had been measured by the Authors in previous field surveys (Tab. S2 in Supplementary material). We included both native species ( $n$ = 206), which also encompass archaeophytes, i.e., alien species introduced in Europe before year 1500 A.D., and neophyte species $(n=15)$, i.e., those introduced in Europe after year 1500 A.D. (Pyšek et al. 2003), the latter being recognised as diagnostic species of some European vegetation classes and not only for alien-dominated classes, namely Robinietea.

Trait data measured by the Authors form part of the TRY global functional trait database (datasets \#227 and \#228 - Kattge et al. 2020), and of the LIFTH database (Dalle Fratte et al. 2021), except for plant height (H) and seed mass (SM), which were derived, respectively, from Pignatti et al. (2017) and Kew Garden Seed Information Database (SID - https://data.kew.org/sid). Methodological procedures for traits measured by Authors are reported in details in Dalle Fratte et al. (2021). To take into account the two main axes of variation of the global spectrum of plant form and function (Díaz et al. 2016), we selected three functional traits, Leaf Area (LA), $\mathrm{H}$ and SM, related to the size of the plant and its organs, and two functional traits, Specific Leaf Area (SLA) and Leaf Nitrogen Content (LNC), highly representative of leaf economics. We also added Carbon to Nitrogen ratio $(\mathrm{C} / \mathrm{N})$ and Leaf Dry Matter Content (LDMC), in order to account for litter de- 
composition and carbon balance (Freschet et al. 2010). Furthermore, LA, LDMC and SLA are traits required by the "StrateFy" classification tool (Pierce et al. 2017), which was used in the present study to calculate the Grime's plant strategies, i.e., the CSR scores (for further methodological details see also Pierce et al. 2013). Species were additionally classified with respect to their growth form (sub-shrubs, $n=77$; shrubs, $n$ = 60; trees, $n=75$; climbers, $n=9$ ) and leaf lifespan (deciduous, $n=163$; evergreen, $n=$
58) according to Pignatti et al. (2017). Complete information about species and their characteristics is reported in the dataset available in Tab. S3 (Supplementary material).

\section{Data analysis}

All the statistical analyses were computed with R software (R Core Team 2020). We applied taxonomic (family and genus) based gap filling, using the function "GapFilling" of the BHPMF package to complete missing data for LNC $(n=3), C / N(n=3)$ and $S M(n=10)$. Gap filling was applied using all data from the Authors' dataset described above $(n=1746)$ in order to include a greater number of taxa, allowing greater prediction accuracy. We then normalized data by logarithmic (LA, H, C/N and SM) or square root (SLA and LNC) transformation according to the outcome of Shapiro-Wilks tests; no transformation was required for LDMC data, which was found to exhibit a normal distribution.

Tab. 1 - List of the 21 classes of European woody vegetation selected for the analysis and their corresponding abbreviation code according to the EuroVeg checklist (Mucina et al. 2016). The number of diagnostic species belonging to each class ( $\mathrm{n}$ ) is reported.

\begin{tabular}{|c|c|c|c|c|}
\hline Code & Class & Description & Vegetation type & $\mathrm{n}$ \\
\hline $\begin{array}{c}\mathrm{AC} \\
(\mathrm{LOI})\end{array}$ & $\begin{array}{l}\text { Loiseleurio procumbentis- } \\
\text { Vaccinietea }\end{array}$ & $\begin{array}{l}\text { Arctic-boreal tundra scrub and relict alpine acidophilous dwarf- } \\
\text { heath mountain tundra of Eurasia and North America }\end{array}$ & $\begin{array}{l}\text { vegetation of the arctic } \\
\text { zone }\end{array}$ & 10 \\
\hline $\begin{array}{l}\mathrm{BA} \\
(\mathrm{PIC})\end{array}$ & Vaccinio-Piceetea & $\begin{array}{l}\text { Holarctic coniferous and boreo-subarctic birch forests on } \\
\text { oligotrophic and leached soils in the boreal zone and at high- } \\
\text { altitudes of mountains in the nemoral zone of Eurasia }\end{array}$ & $\begin{array}{l}\text { vegetation of the boreal } \\
\text { zone }\end{array}$ & 19 \\
\hline $\begin{array}{l}\text { CA } \\
\text { (FAG) }\end{array}$ & Carpino-Fagetea sylvaticae & $\begin{array}{l}\text { Mesic deciduous and mixed forests of temperate Europe, Anatolia, } \\
\text { the Caucasus and Southern Siberia }\end{array}$ & $\begin{array}{l}\text { vegetation of the nemoral } \\
\text { forest zone }\end{array}$ & 40 \\
\hline $\begin{array}{l}\text { CB } \\
\text { (PUB) }\end{array}$ & Quercetea pubescentis & $\begin{array}{l}\text { Oak, mixed deciduous and conifer woods of warm regions in the } \\
\text { cool-temperate nemoral zone of Central and Southern Europe and } \\
\text { in the supramediterranean belt of the Mediterranean, Asia Minor } \\
\text { and Middle East }\end{array}$ & $\begin{array}{l}\text { vegetation of the nemoral } \\
\text { forest zone }\end{array}$ & 34 \\
\hline $\begin{array}{l}\text { CC } \\
\text { (QUE) }\end{array}$ & Quercetea robori-petraeae & $\begin{array}{l}\text { Acidophilous oak and oak-birch forests on nutrient-poor soils of } \\
\text { Europe }\end{array}$ & $\begin{array}{l}\text { vegetation of the nemoral } \\
\text { forest zone }\end{array}$ & 10 \\
\hline $\begin{array}{l}\mathrm{CD} \\
(\mathrm{RHA})\end{array}$ & Crataego-Prunetea & $\begin{array}{l}\text { Scrub and mantle vegetation seral or marginal to broad-leaved } \\
\text { forests in the nemoral zone and the submediterranean regions of } \\
\text { Europe }\end{array}$ & $\begin{array}{l}\text { vegetation of the nemoral } \\
\text { forest zone }\end{array}$ & 41 \\
\hline $\begin{array}{l}\text { CE } \\
(\text { LON })\end{array}$ & Lonicero-Rubetea plicati & $\begin{array}{l}\text { Acidophilous scrub and hedges of forest edges and clearings on dry } \\
\text { sandy nutrient-poor minerotrophic soils of Western Europe }\end{array}$ & $\begin{array}{l}\text { vegetation of the nemoral } \\
\text { forest zone }\end{array}$ & 6 \\
\hline $\begin{array}{l}\mathrm{CF} \\
(\mathrm{ROB})\end{array}$ & Robinietea & $\begin{array}{l}\text { Seral forest-clearing and anthropogenic successional scrub and } \\
\text { thickets on nutrient-rich soils of temperate Europe }\end{array}$ & $\begin{array}{l}\text { vegetation of the nemoral } \\
\text { forest zone }\end{array}$ & 15 \\
\hline $\begin{array}{l}\mathrm{CH} \\
(\mathrm{ULI})\end{array}$ & Calluno-Ulicetea & $\begin{array}{l}\text { Heath on acidic nutrient-poor soils in the lowland to montane } \\
\text { belts of the temperate and boreal zones of Europe }\end{array}$ & $\begin{array}{l}\text { vegetation of the nemoral } \\
\text { forest zone }\end{array}$ & 8 \\
\hline $\begin{array}{l}C N \\
(\mathrm{SAB})\end{array}$ & Junipero-Pinetea sylvestris & $\begin{array}{l}\text { Relict oromediterranean and submediterranean orotemperate dry } \\
\text { pine forests, juniper woods and related scrub of the } \\
\text { Mediterranean }\end{array}$ & $\begin{array}{l}\text { vegetation of the nemoral } \\
\text { forest zone }\end{array}$ & 5 \\
\hline $\begin{array}{l}\mathrm{CO} \\
(\mathrm{ERI})\end{array}$ & Erico-Pinetea & $\begin{array}{l}\text { Relict pine forests and related scrub on calcareous and ultramafic } \\
\text { substrates of the Balkans, the Alps, the Carpathians and Crimea }\end{array}$ & $\begin{array}{l}\text { vegetation of the nemoral } \\
\text { forest zone }\end{array}$ & 14 \\
\hline $\begin{array}{c}\text { CP } \\
(M U G)\end{array}$ & $\begin{array}{l}\text { Roso pendulinae-Pinetea } \\
\text { mugo }\end{array}$ & $\begin{array}{l}\text { Pine krummholz in the subalpine belts of the nemoral mountain } \\
\text { ranges of Europe }\end{array}$ & $\begin{array}{l}\text { vegetation of the nemoral } \\
\text { forest zone }\end{array}$ & 7 \\
\hline $\begin{array}{c}\mathrm{CQ} \\
(\mathrm{RHO})\end{array}$ & $\begin{array}{l}\text { Rhododendro hirsuti- } \\
\text { Ericetea carneae }\end{array}$ & $\begin{array}{l}\text { Supramontane to subalpine low heath on calcareous skeletal soils, } \\
\text { rocky outcrops, lapiés and boulders of the Alps, the Apennines and } \\
\text { the Dinarides }\end{array}$ & $\begin{array}{l}\text { vegetation of the nemoral } \\
\text { forest zone }\end{array}$ & 8 \\
\hline $\begin{array}{l}C R \\
(V I R)\end{array}$ & $\begin{array}{l}\text { Betulo carpaticae-Alnetea } \\
\text { viridis }\end{array}$ & $\begin{array}{l}\text { Subalpine and subarctic herb-rich alder and willow scrub and } \\
\text { krummholz of the Alps, the Carpathians, the Hercynicum, the } \\
\text { Balkans, the Caucasus, Northern Europe and Greenland }\end{array}$ & $\begin{array}{l}\text { vegetation of the nemoral } \\
\text { forest zone }\end{array}$ & 12 \\
\hline $\begin{array}{l}\text { FA } \\
(Q U I)\end{array}$ & Quercetea ilicis & $\begin{array}{l}\text { Thermo-mesomediterranean pine and oak forests and associated } \\
\text { macchia of the Mediterranean }\end{array}$ & $\begin{array}{l}\text { vegetation of the } \\
\text { mediterranean zone }\end{array}$ & 29 \\
\hline $\begin{array}{l}\text { FB } \\
\text { (ROS) }\end{array}$ & Ononido-Rosmarinetea & $\begin{array}{l}\text { Mediterranean scrub (tomillar, espleguer, romeral, garrigue, } \\
\text { phrygana, batha) on base-rich substrates }\end{array}$ & $\begin{array}{l}\text { vegetation of the } \\
\text { mediterranean zone }\end{array}$ & 17 \\
\hline $\begin{array}{l}\text { FC } \\
(\mathrm{LAV})\end{array}$ & Cisto-Lavanduletea & $\begin{array}{l}\text { Mediterranean scrub (jaral, matorral, garrigue, phrygana) on } \\
\text { acidic siliceous and ultramafic substrates }\end{array}$ & $\begin{array}{l}\text { vegetation of the } \\
\text { mediterranean zone }\end{array}$ & 6 \\
\hline $\begin{array}{l}\text { HA } \\
\text { (POP) }\end{array}$ & $\begin{array}{l}\text { Alno glutinosae-Populetea } \\
\text { albae }\end{array}$ & $\begin{array}{l}\text { Riparian gallery forests of the Eurosiberian and Mediterranean } \\
\text { regions }\end{array}$ & alluvial forests and scrubs & 23 \\
\hline $\begin{array}{l}\mathrm{HB} \\
\text { (PUR) }\end{array}$ & Salicetea purpureae & $\begin{array}{l}\text { Willow and tamarisk scrub and low open forests of riparian } \\
\text { habitats in the temperate to arctic zones of Europe and Greenland }\end{array}$ & alluvial forests and scrubs & 7 \\
\hline $\begin{array}{l}\text { IA } \\
(\mathrm{ALN})\end{array}$ & Alnetea glutinosae & $\begin{array}{l}\text { European mesotrophic regularly flooded alder carr and birch } \\
\text { wooded mires }\end{array}$ & swamp forests and scrubs & 6 \\
\hline $\begin{array}{l}\mathrm{PB} \\
(\mathrm{OXY})\end{array}$ & Oxycocco-Sphagnetea & $\begin{array}{l}\text { Dwarf-shrub, sedge and peat-moss vegetation of the Holarctic } \\
\text { ombrotrophic bogs and wet heath on extremely acidic soils }\end{array}$ & vegetation of bogs and fens & 5 \\
\hline
\end{tabular}


To confirm whether the global spectrum of plant form and function (Díaz et al. 2016) was reflected within our dataset, we performed a Principal Component Analysis (PCA), followed by varimax rotation, on functional traits data using the "principal" function in the package "psych". After determining the significant components of the PCA (i.e., those that explained most of the dataset total variance), we tested, within the PCA multidimensional space, for differences in the spatial arrangement of growth forms and leaf lifespans, by means of multivariate analysis of variance (MANOVA). We then applied one-way analysis of variance (ANOVA), followed by post-hoc pairwise comparison, to identify significant differences of growth forms and leaf lifespans along each significant component of the PCA. In order to control for the effects of phylogenetic correlation (Westoby et al. 1995), we built a phylogenetic tree and applied phylogenetic MANOVA by means of the "aov.phylo" function of the package "geiger", and phylogenetic ANOVA with post-hoc tests using respectively the functions "phylANOVA" and "multcompLetters" of packages "phytools" and "multcompView".

We then investigated whether the functional spectrum of the classes differed from each other according to their physiognomy, through hierarchical clustering on principal components using the function "HCPC" of the package "FactoMineR". The consistency of gained clusters was checked within the ternary space determined by CSR strategies by means of phylogenetic MANOVA. To account for the compositional structure of the CSR data we first transformed the dataset of CSR scores with Isometric Log-Ratio Transformation, which reduced the ternary dataset to a two-dimension image (see Dalle Fratte
Fig. 1 - Main variation among functional traits of woody diagnostic species. Principal Component Analysis on trait values of the 221 woody diagnostic species considered for the analysis grouped by growth form and leaf life span (deciduous: DC; evergreen: EV)

(a), and neophyte vs. native species (b). Mean values of the classes (full names are reported in Tab. 1) are also shown (b), grouped by the cluster they belong to (Fig. $\mathrm{S} 4$ in Supplementary material). Lines represent the $50^{\text {th }}$ percentile of the distribution of neophyte (solid line) and native species (dashed line). $(\mathrm{C} / \mathrm{N})$ : carbon to nitrogen ratio; $(\mathrm{H})$ : plant height; (LA): leaf area; (LDMC): leaf dry matter content; (LNC): leaf nitrogen content; (SLA): specific leaf area; (SM): seed mass.
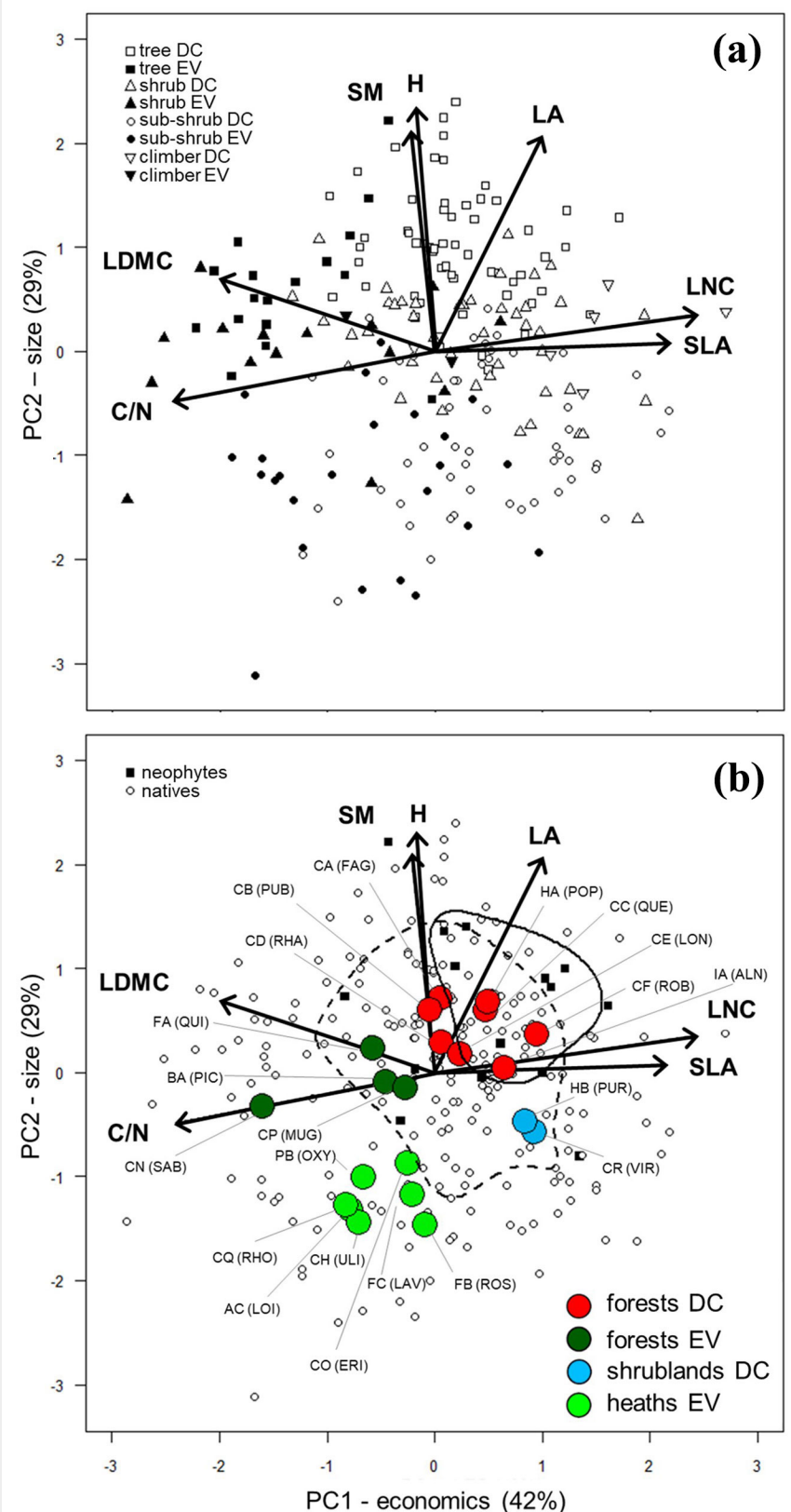

et al. 2019a, and references therein). We also compared the $\mathrm{C}-$, S-, and R-scores through phylogenetic ANOVA followed by post-hoc comparison. We used the R-package "ggtern" to visualize the ternary plot of CSR strategies. Finally, we compared native and neophyte species along both significant components of the PCA as well as C-, S- and R-scores by means of phylogenetic ANOVA.

\section{Phylogenetic tree}

We built the phylogenetic tree for the study species using the megaphylogeny tree implemented in the package "V.PhyloMaker". We adopted their "Scenario 1" to solve the phylogeny at the species level in our dataset, since it is the most cautious and avoids random solutions by adding genera or species as basal polytomies within families or genera. The phylogeny implemented in the package "V.PhyloMaker" was based on nomenclature standardization according to The Plant List (TPL, http://www.theplantlist.org). Hence, before processing the phylogenetic tree, we standardized names of every taxon (family, genus and species) in our dataset according to TPL, using the package "Taxonstand".

\section{Results}

The first two principal components ( $\mathrm{PC}_{1}$ and $P(2)$ of the PCA together explained a large amount $(71 \%)$ of the dataset total variance (respectively, $42 \%$ and $29 \%$ ). Functional traits displayed a specific pattern along the PCA axes: PC1 correlated positively with SLA and LNC and negatively with $L D M C$ and $C / N$, while $P C 2$ correlated positively with LA, H and SM (Fig. 1a, Tab. 2). This displacement reflected the variation from conservative to acquisitive leaf traits along PC1 (thus representing the leaf economics spectrum), and the increase in size dimensions of plants and their organs along PC2. Moreover, both leaf lifespan (Wilks $=0.59$, approx. $-\mathrm{F}=74.4$, phylog. corrected $p<0.001$ ) and growth form categories (Wilks $=0.37$, approx.-F $=46.1$, phylog. corrected $p<0.001$ ) displaced significantly differently in the multidimensional space of the PCA, mirroring functional trait variation. Leaf lifespan showed significant differences only along the "PC1-economics" axis, with deciduous species being relatively acquisitive compared to evergreen species, while growth form variation was related to the "PC2-size" axis, with trees exhibiting higher values opposed to subshrubs (Fig. S2 in Supplementary material).

The two dimensions of plant form and function were strongly reflected also among classes. Both PC1-economics (eta ${ }^{2}=$ $0.72, \mathrm{p}<0.001)$ and PC2-size (eta ${ }^{2}=0.93, \mathrm{p}$ $<0.001$ ) contributed significantly in the delimitation of four groups of classes: (i) evergreen heaths and scrubs; (ii) deciduous shrublands (meso-hygrophilous formations of avalanche slopes and riparian habitats); (iii) evergreen forests (including both coni- 
ferous and sclerophyllous formations); and (iv) deciduous forests (Fig. $\mathrm{S}_{3}$ in Supplementary material). Specifically, along the PC1-economics axis, deciduous forests and, even more so, deciduous shrublands, showed more acquisitive characteristics compared to heaths and scrubs as well as evergreen forest, with the class Robinieto (CF.ROB) being the most acquisitive, as opposed to the most conservative JuniperoPinetea sylvestris (CN.SAB). Along the PC2size axis, both deciduous and evergreen forests exhibited higher values compared to heaths and scrubs as well as deciduous shrublands. Specifically, deciduous forests showed the highest mean values with the class Carpino-Fagetea sylvaticae (CA.FAG) and Alno glutinosae - Populetea albae (HA.POP), as opposed to the lowest mean values of the heath and scrub classes Ononido-Rosmarinetea (FB.ROS) and Calluno-Ulicetea (CH.ULI - Fig. S4 in Supplementary material).

Considering the ternary CSR plant strategy space (Fig. 2), the mean values of classes were ordinated essentially along a gradient from stress-tolerant (S) to competitive (C) strategies. Deciduous forests exhibited significantly higher mean values of C-scores than evergreen forests as well as heath and scrub classes, which conversely had significantly higher mean values of S-scores. Specifically, the class Junipero-Pinetea sylvestris (CN.SAB) was the most stress-tolerant, as opposed to the most competitive (and neophyte-dominated) class Robinietea (CF.ROB). We did not find differences among these groups of classes regarding their R-scores (Fig. $\mathrm{S}_{5}$ in Supplementary material), despite a slight tendency of deciduous shrublands towards ruderal strategies.

Neophytes displayed both higher acquisitive characteristics and larger size of their leaves and seeds (i.e., higher mean value along both PC1-economics and PC2-size), and simultaneously showed a greater mean value of C-scores and lower of Sscores. We did not find significant differences of neophytes in terms of R-scores (Fig. 1b, Fig. 2, and Fig. S6 in Supplementary material).

\section{Discussion}

Functional dimension of European woody vegetation classes in Northern Italy

Our results demonstrate that the functional characteristics of woody species, diagnostic of phytosociological classes of European woody vegetation, can effectively embody the physiognomy and the ecology of the vegetation they represent, supporting our first hypothesis. Trade-offs among the considered traits were well captured by the first two dimensions of principal component analysis (Fig. 1a), showing that variation in resource economics and size relevant to woody species (Fyllas et al. 2020) matches vegetation units resolved
Tab. 2 - Pearson's correlation coefficients ( $r$ ) and level of significance (p) of trait values with the first two axes of the Principal Component Analysis (PC1 and PC2) for the 221 study species $(\mathrm{df}=219)$. $(\mathrm{C} / \mathrm{N})$ : carbon to nitrogen ratio; $(\mathrm{H})$ : plant height; $(\mathrm{LA})$ : leaf area; (LDMC): leaf dry matter content; (LNC): leaf nitrogen content; (SLA): specific leaf area; (SM): seed mass; (ns): not significant; $\left(^{*}\right): p \leq 0.05 ;(* *): p \leq 0.01 ;(* * *)$ : $\mathrm{p} \leq 0.001$.

\begin{tabular}{lcccc}
\hline \multirow{2}{*}{ Plant trait } & \multicolumn{2}{c}{ PC1 } & \multicolumn{3}{c}{ PC2 } \\
\cline { 2 - 5 } & $\mathbf{r}$ & $\mathbf{p}$ & $\mathbf{r}$ & $\mathbf{P}$ \\
\hline C/N & -0.90 & $* * *$ & -0.18 & $*$ \\
\hline H & -0.06 & ns & 0.86 & $* * *$ \\
\hline LA & 0.37 & $* * *$ & 0.76 & $* * *$ \\
\hline LDMC & -0.74 & $* * *$ & 0.25 & $* * *$ \\
\hline LNC & 0.90 & $* * *$ & 0.13 & $*$ \\
\hline SLA & 0.80 & $* * *$ & 0.03 & ns \\
\hline SM & -0.08 & ns & 0.78 & $* * *$ \\
\hline
\end{tabular}

by phytosociology. We determined that European woody vegetation classes of Northern Italy highlight two main axes of variation: the first represented the leaf economics axis (Wright et al. 2004), ranging from resource-acquisitive communities, e.g., classes Alnetea glutinosae (IA.ALN) and Betulo carpaticae-Alnetea viridis (CR.VIR), to resource-conservative ones typical of evergreen classes, such as Junipero-Pinetea silvestris (CN.SAB). The second axis corresponds to size variation, spanning from short-stature and light-seeded communi- ties typical of heath and scrub classes, e.g., Ononido-Rosmarinetea (FB.ROS) and Calluno-Ulicetea (CH.ULI), to tall-stature and possibly heavy-seeded communities typical of forests classes, e.g., Carpino-Fagetea sylvaticae (CA.FAG) and Alno glutinosae-Populetea albae (HA.POP). These adaptive trends were similar to those described globally both at the species-level (Díaz et al. 2016) and at the community-level (Bruelheide et al. 2018), confirming the convergence of the evolutionary history of single species with community assembly. Com-

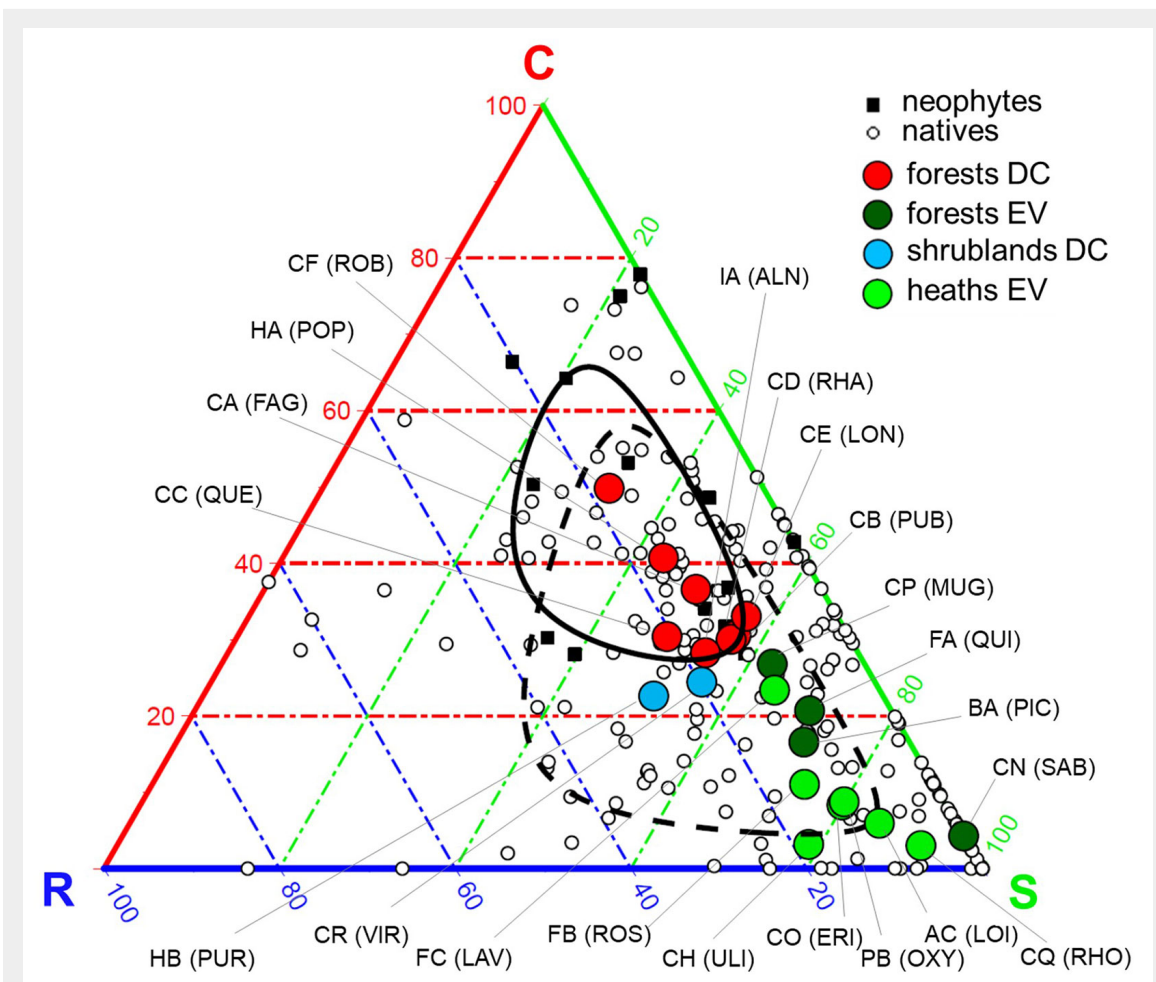

Fig. 2 - Plant adaptive strategies of woody diagnostic species. Ternary visualization of Grime's CSR (Competitive, Stress-tolerant, Ruderal) plant strategies of the 221 woody diagnostic species selected for the analysis, showing neophyte vs. native species, and mean values of classes (full names are reported in Tab. 1), grouped by the cluster they belong to (see Fig. S4 in Supplementary material). Lines represent the $50^{\text {th }}$ percentile of the distribution of neophyte (solid line) and native species (dashed line). (DC): deciduous; (EV): evergreen. 
pared to the work of Bruelheide et al. (2018), who considered species abundance data, our analysis - referred to diagnostic species regardless of their abundance stresses the strong ecological significance of diagnostic species. Whereas globally the size axis was the most relevant in explaining the total variance of species and communities, we observed that the PC1-economics captured most of the total variance of our dataset. This result is presumably due to the presence of both woody and herbaceous species (Díaz et al. 2016) or communities (Bruelheide et al. 2018) in the analyzed datasets, while we only considered woody species, which are known to be mainly differentiated by resource economics (De la Riva et al. 2016, Leuschner \& Meier 2018, Rueda et al. 2018).

Woody vegetation classes were ordinated within the two-dimensional space of the PCA according to four main physiognomic groups, as identified by the cluster analysis (Fig. 1b). Classes of evergreen heaths and scrubs, as well as of evergreen forests, converged toward lower values of the economics axis, thus exhibiting conservative leaf traits. These groups include classes dominated by needle-leaved and sclerophyllous species, typical of borealalpine climatic zones, e.g., Loiseleurio procumbentis-Vaccinietea (AC.LOI), Rhododendro hirsuti-Ericetea carneae (CQ.RHO), Vaccinio-Piceetea (BA.PIC) and Roso pendulinae-Pinetea mugo (CP.MUG), or Mediterranean climate, e.g., Cisto-Lavanduletea stoechadis (FC.LAV), Ononido-Rosmarinetea (FB.ROS), Junipero-Pinetea sylvestris (CN.SAB) and Quercetea ilicis (FA.QUI), and therefore include species adapted to endure adverse environmental conditions such as drought, extreme temperatures (high and/or low) and prolonged snow cover (De la Riva et al. 2016, Fyllas et al. 2020, Zanzottera et al. 2020). Indeed, classes of both evergreen heaths and forests showed a marked tendency toward the stress-tolerant (S) strategy (Fig. 2), confirming also for woody vegetation that in harsh habitats the environmental filter (i.e., abiotic stress) is a key determinant of the community functional composition (Thonicke et al. 2020), leading species to share similar traits as a common adaptation to physical constraints (Grime 2006, De Bello et al. 2009). Our results support evidence of a convergence toward similar functional response of structural diagnostic species of syntaxa that phytosociology considers to be completely different, as they do not exhibit species in common.

Classes of deciduous forests showed an overall prominent competitive strategy, with high mean values of C-selection (Fig. 2 ). These communities are typical of temperate climates and productive environments with abundant resources, and occur under much less severe ecological constraints (Kunstler et al. 2016, Leuschner \& Meier 2018, Costa-Saura et al. 2019). These habitat characteristics make environmental filters weaker, allowing more inter- and intra-specific interactions, and hence competition becomes the main driver shaping the functional character of the community (Grime \& Pierce 2012). Despite classes of deciduous forest being very similar in their functional properties, it was possible to identify some differences. Some communities were dominated by species denoted by a lesser resource allocation to stem and seeds (i.e., low $\mathrm{H}$ and $\mathrm{SM}$ ) and leaves with fast economics traits (i.e., high SLA and LNC - Fig. 1b), which implies rapid growth and nutrient acquisition, typical of classes of wet environments (e.g., Alnetea glutinosae, IA.ALN) or that could occur as pioneers during secondary succession in temperate forests (e.g., Robinietea, CF.ROB Silva et al. 2015, Costa-Saura et al. 2019). Alternatively, species of other classes showed a major investment in larger seeds, plant height and thicker leaves with slow resource economics characteristics (Fig. 1b), typical of classes corresponding to later successional stages (e.g., CarpinoFagetea sylvaticae, CA.FAG; Quercetea pubescentis, CB.PUB; and Quercetea robori-petraeae, CC.QUE - Silva et al. 2015).

Our results demonstrated that the sets of woody species diagnostic for phytosociological classes mainly vary between S- and C-selection, as previously observed at the single species level at both European and global scales (Pierce et al. 2013, 2017). All the diagnostic species exhibited low mean values of R- selection, which indicates that they are not successful in habitats with a high intensity of disturbance (Pierce et al. 2013). Actually, Brzeziecki \& Kienast (1994) classified some tree species as ruderal ( 9 out of 36 studied), considering them as pioneers that colonize gaps in the forest canopy (with a short lifespan, a high potential growth rate and a long-distance seeds dispersal), but Pierce et al. (2017) argue that pioneer trees are classified as C-selected because disturbance is not a regular occurrence (in the same way as annual mowing or grazing) and plants can attain large size without being killed. Thus "pioneer" is not necessarily synonymous with "ruderal". Moreover, in the global spectrum of plant form and function (Díaz et al. 2016) only herbaceous species are found at the most acquisitive end of the leaf economics axis, which broadly corresponds to the ruderal strategy. Nonetheless, woody diagnostic species of deciduous shrub formations (Salicetea purpureae, HB.PUR and Betulo carpaticae - Alnetea viridis, CR.VIR) displayed traits (i.e., small size and acquisitive resource economics - Fig. 1b) which reflected their greater adaptation to survive destructive events typical of their habitat, due to high-energy water and snow flows, such as avalanches, snow creep, floods and waterlogging (Leuschner \& Ellenberg 2017). Despite the fact that these two classes showed a tendency towards R-selection because of the disturbance they are exposed to, our results emphasize that, as a general rule, woody diagnostic species display only low values of R-selection. This outcome confirms that vegetation classes they represent are not successful in intensely disturbed habitats (Fig. 2, Fig. $S_{5}$ in Supplementary material), because woody perennial species require time and stability to accumulate biomass (Pierce et al. 2017), while marked acquisitive characteristics are distinctive of other, non-woody, life forms that do not rely on achieving large size over many growth seasons.

\section{Functional trade-offs among woody diagnostic species of alien and native and invasion threat}

The set of diagnostic species of Robinietea (CF.ROB), a neophytes-dominated class recognized as part of European natural vegetation (Mucina et al. 2016, Viciani et al. 2020), exhibited the highest degree of competition among all the considered classes. In fact, all neophyte species were highly C-selected with a slight tendency toward the ruderal strategy (Fig. 2); these species showed effective resource acquisition traits, having large leaves with high nutrient content (i.e., high SLA, LA and LNC), and rapid and extensive growth (i.e., high H - Fig. 1b). Alien woody species tend to occupy disturbed environments, often as part of secondary succession (Pyšek et al. 2017), and they are also efficient competitors that thrive in high-resource environments (Dalle Fratte et al. 2019a). This confirms that the establishment of neophyte species is associated with ruderal and competitive strategies, whereas these species are not successful in heavily stressed habitats (Guo et al. 2018). Yet, Guo et al. (2018) observed that the naturalization incidence and extent of alien trees at the global scale were not correlated with either C-, S-, or R- scores, due to the low number of tree species in the global pool of naturalized plants. Instead, in our dataset, trees represented more than half of the neophyte species ( 8 out of 15), and two of them also showed the highest Cscores (Trachycarpus fortunei and Ailanthus altissima - Tab. S3 in Supplementary Material), suggesting that the link between competitive strategy and naturalization success can be noticeable even in trees. Therefore, if an increment in disturbance and/or in resource availability should occur in habitats exploited by woody vegetation classes of harsh-climate environments as a consequence of global change, favourable niches could become accessible to alien woody species that might significantly affect these communities (Davis et al. 2000). For instance, montane regions are known to be particularly threatened by climate warming that facilitates woody alien species invasion, especially in already endangered habitats (Kleinbauer et al. 2010).

\section{Conclusion}

In this study we found, for phytosociological classes of European woody vegetation, 
a clear correspondence between the functional ecology of their woody diagnostic species and the physiognomy and ecology of the communities they represent. This confirms that functional traits and plant adaptive strategies reliably indicate plantenvironment relations in accordance with the floristic classification on which syntaxonomy is based. Such correspondence was particularly evident among classes of evergreen heaths, scrubs and forests, typical of extreme environments (boreal-alpine and mediterranean) that showed a convergence toward species exhibiting conservative characteristics and stress-tolerant strategies, due to the environmental filter that imposes a common adaptation to abiotic constraints. More favourable and productive environments, exploited by deciduous forests, rather selected for species with a tendency toward competitive strategies. Accordingly, we highlighted that abiotic stress and biotic competition are the main ecological drivers that affect woody vegetation, while no vegetation class showed a marked ruderal strategy linked to highly recurrent disturbance. Neophyte woody species, which currently represent one of the major threats affecting plant assemblages, exhibited relatively competitive strategies than native woody species. This evidence implies that resource-limited or mildly disturbed environments, now occupied by native species, could be the most exposed to alien species invasion, should a climate warming or a nutrient increase occur.

We can conclude that woody diagnostic species can reliably indicate both structure and functions of woody vegetation classes coherently with their ecological characteristics. Our results represent a progress toward the integration of phytosociology and functional ecology, opening the way to what could be called "functional phytosociology". Anyway, this approach could be valuable for more accurate analysis within conservation programs, as in the planning of sustainable management guidelines of EFTs and especially in the monitoring of habitat types (sensu Habitats Directive) identified with specific syntaxa. At least for woody vegetation, we were able to demonstrate that "functional phytosociology" can improve the knowledge of structure and functions, as required by the Habitat Directive for the identification of typical species to be used for the assessment of the conservation status of habitat types.

\section{Acknowledgements}

BELC and MDF designed the study and organized the field sampling; MDF and MZ collected and processed samples, and analyzed the data; $M Z$ wrote the first draft of the manuscript and all authors commented and revised the manuscript.

We thank Andrea Gianotti, Martina Guglielmi, Matteo Francocci, Lucrezia Daniele and Federico Mattiazzo for assistance in the field-sampling and in the laboratory analysis of functional traits data.

This study was funded by Fondazione Lombardia per l'Ambiente (FLA).

\section{References}

Barbati A, Marchetti M, Chirici G, Corona P (2014). European forest types and forest Europe SFM indicators: tools for monitoring progress on forest biodiversity conservation. Forest Ecology and Management 321: 145-157. doi: 10.1016/j.foreco.2013.07.004

Becking RW (1957). The Zürich-Montpellier school of phytosociology. The Botanical Review 23 (7): 411-488. - doi: 10.1007/BF02872328

Blasi C, Burrascano S (2013). The role of plant sociology in the study and management of European forest ecosystems. iForest - Biogeosciences and Forestry 6 (2): 55-58. - doi: 10.3832/ iforog13-006

Bonari G, Fantinato E, Lazzaro L, Sperandii MG, Acosta ATR, Allegrezza M, Assini S, Caccianiga M, Di Cecco V, Frattaroli A, Gigante D, Rivieccio G, Tesei G, Valle B, Viciani D, Albani Rocchetti G, Angiolini C, Badalamenti E, Barberis D, Barcella M, Bazan G, Bertacchi A, Bolpagni R, Bonini F, Bricca A, Buffa G, Calbi M, Cannucci S, Cao Pinna L, Caria MC, Carli E, Cascone S, Casti M, Cerabolini BEL, Copiz R, Cutini M, De Simone L, De Toma A, Dalle Fratte M, Di Martino L, Di Pietro R, Filesi L, Foggi B, Fortini P, Gennaio R, Gheza G, Lonati M, Mainetti A, Malavasi M, Marcenò C, Micheli C, Minuzzo C, Mugnai M, Musarella CM, Napoleone F, Nota G, Piga G, Pittarello M, Pozzi I, Praleskouskaya S, Rota F, Santini G, Sarmati S, Selvaggi A, Spampinato G, Stinca A, Tozzi FP, Venanzoni R, Villani $M$, Zanatta K, Zanzottera $M$, Bagella $S$ (2021). Shedding light on typical species: implications for habitat monitoring. Plant Sociology 58 (1): 157-166. - doi: 10.3897/pls 2020581/08

Braun-Blanquet J (1932). Plant sociology, the study of plant communities ( $1^{\text {st }}$ edn). McGrawHill Book Co., New York, USA, pp. 439.

Bruelheide H, Dengler J, Purschke O, Lenoir J, Jiménez-Alfaro $B$, Hennekens SM, Botta-Dukát Z, Chytry M, Field R, Jansen F, Kattge J, Pillar VD, Schrodt F, Mahecha MD, Peet RK, Sandel B, Van Bodegom P, Altman J, Alvarez-Dávila E, Arfin Khan MAS, Attorre F, Aubin I, Baraloto C, Barroso JG, Bauters M, Bergmeier E, Biurrun I, Bjorkman AD, Blonder B, Cayuela L, Cornelissen JHC, Craven D, Dainese M, Derroire G, De Sanctis $M$, Díaz $S$, Doleal J, Farfan-Rios W, Feldpausch TR, Fenton NJ, Garnier E, Guerin GR, Gutiérrez AG, Haider S, Hattab T, Henry G, Hérault $B$, Higuchi $P$, Hölzel $N$, Homeier J, Jentsch $A$, Jürgens N, Karger DN, Kessler M, Kleyer M, Knollová I, Korolyuk AY, Kühn I, Laughlin DC, Lens F, Loos J, Louault F, Lyubenova MI, Malhi Y, Marcen A, Mencuccini M, Müller JV, Munzinger J, Myers-Smith IH, Neill DA, Niinemets $U$, Orwin $\mathrm{KH}$, Ozinga WA, Penuelas J, Pérez-Haase A, Pet A, Phillips OL, Pärtel M, Reich PB, Römermann C, Rodrigues AV, Sabatini FM, Sardans J, Schmidt M, Seidler G, Espejo JES, Silveira M, Smyth A, Sporbert M, Svenning JC, Tang Z, Thomas R, Tsiripidis I, Vassilev K, Violle C, Virtanen $R$, Weiher $E$, Welk $E$, Wesche $K$, Winter $M$, Wirth C, Jandt U (2018). Global trait-environment relationships of plant communities. $\mathrm{Na}$ ture Ecology and Evolution 2 (12): 1906-1917. doi: 10.1038/s41559-018-0699-8

Brzeziecki B, Kienast F (1994). Classifying the lifehistory strategies of trees on the basis of the Grimian model. Forest Ecology and Management 69 (1-3): 167-187. - doi: 10.1016/03781127(94)90227-5

Chytry M, Tichy L, Holt J, Botta-Dukát Z (2002). Determination of diagnostic species with statistical fidelity measures. Journal of Vegetation Science 13 (1): 79-90. - doi: 10.1111/j.1654-1103. 2002.tbo2025.x

Costa-Saura JM, Trabucco A, Spano D, Mereu S (2019). A height-wood-seed axis which is preserved across climatic regions explains tree dominance in European forest communities. Plant Ecology 220 (4-5): 467-480. - doi: 10.1007/ s11258-019-00928-x

Dalle Fratte $M$, Bolpagni R, Brusa G, Caccianiga $M$, Pierce S, Zanzottera M, Cerabolini BEL (2019a). Alien plant species invade by occupying similar functional spaces to native species. Flora 257 (2): 151419. - doi: 10.1016/j.flora.2019. 151419

Dalle Fratte M, Brusa G, Cerabolini BEL (2019b). A low-cost and repeatable procedure for modelling the regional distribution of Natura 2000 terrestrial habitats. Journal of Maps 15 (2): 7988. - doi: 10.1080/17445647.2018.1546625

Dalle Fratte M, Pierce S, Zanzottera M, Cerabolini BEL (2021). The association of leaf sulfur content with the leaf economics spectrum and plant adaptive strategies. Functional Plant Biology 48 (9): 924-935. - doi: 10.1071/FP20396

Davis MA, Grime JP, Thompson K (2000). Fluctuating resources in plant communities: a general theory of invasibility. Journal of Ecology 88 (3): 528-534. - doi: 10.1046/j.1365-2745.2000.00473.x De Bello F, Thuiller W, Lepš J, Choler P, Clément JC, Macek P, Sebastià MT, Lavorel S (2009). Partitioning of functional diversity reveals the scale and extent of trait convergence and divergence. Journal of Vegetation Science 20 (3): 475-486. - doi: 10.1111/j.1654-1103.2009.01042.x

De La Riva EG, Tosto A, Pérez-Ramos IM, Navarro-Fernández CM, Olmo M, Anten NPR, Marañón T, Villar R (2016). A plant economics spectrum in Mediterranean forests along environmental gradients: is there coordination among leaf, stem and root traits? Journal of Vegetation Science 27 (1): 187-199. - doi: 10.1111/jvs.12 341

Díaz S, Cabido M (2001). Vive la différence: plant functional diversity matters to ecosystem processes. Trends in Ecology and Evolution 16: 646-655. - doi: 10.1016/S0169-5347(01)02283-2 Díaz S, Kattge J, Cornelissen JHC, Wright IJ, Lavorel S, Dray S, Reu B, Kleyer M, Wirth C, Prentice IC, Garnier E, Bönisch G, Westoby M, Poorter H, Reich PB, Moles AT, Dickie J, Gillison AN, Zanne AE, Chave J, Wright SJ, Sheremetev SN, Jactel H, Baraloto C, Cerabolini BEL, Pierce S, Shipley S, Kirkup D, Casanoves F, Joswig JS, Günther A, Falczuk V, Rüger N, Mahecha MD, Gorné LD (2016). The global spectrum of plant form and function. Nature 529 (7585): 167-171. doi: 10.1038/nature16489

Dick JTA, Laverty C, Lennon JJ, Barrios-ON, Mensink PJ, Britton JR, Médoc V, Boets P, Alexander ME, Taylor NG, Dunn AM, Hatcher MJ, Rosewarne PJ, Crookes S, Maclsaac HJ, Xu M, Ricciardi A, Wasserman RJ, Ellender BR, 
Weyl OLF, Lucy FE, Banks PB, Dodd JA, MacNeil C, Penk MR, Aldridge DC, Caffrey JM (2017). Invader Relative Impact Potential: a new metric to understand and predict the ecological impacts of existing, emerging and future invasive alien species. Journal of Applied Ecology 54 (4): 1259-1267. - doi: 10.1111/1365-2664.12849

EEA (2006). European forest types. Categories and types for sustainable forest management and reporting. Report no. 9/2006, European Environment Agency - EEA, Copenhagen, Denmark, pp. 114. [online] URL: http://www.eea.eu ropa.eu/publications/technical_report_2006_9 Freschet GT, Cornelissen JH, Van Logtestijn RS, Aerts R (2010). Evidence of the "plant economics spectrum" in a subarctic flora. Journal of Ecology 98 (2): 362-373. - doi: 10.1111/j.1365-274 5.2009.01615.x

Fyllas NM, Michelaki C, Galanidis A, Evangelou E, Zaragoza-Castells J, Dimitrakopoulos PG, Tsadilas C, Arianoutsou M, Lloyd J (2020). Functional trait variation among and within species and plant functional types in mountainous Mediterranean forests. Frontiers in Plant Science 11: 25. - doi: $10.3389 /$ fpls.2020.00212

Garnier E, Navas ML, Grigulis K (2016). Plant functional diversity: organism traits, community structure, and ecosystem properties. Oxford University Press, Oxford, UK, pp. 231. - doi: 10.1093/acprof:oso/9780198757368.001.0001 Giannetti F, Barbati A, Mancini LD, Travaglini D, Bastrup-Birk A, Canullo R, Nocentini S, Chirici G (2018). European forest types: toward an automated classification. Annals of Forest Science 75 (1): 1-14. - doi: 10.1007/s13595-017-0674-6 Grime JP (2001). Plant strategies, vegetation processes, and ecosystem properties ( $\left.2^{\text {nd }} e d n\right)$. John Wiley and Sons Ltd, Chichester, UK, pp. 456.

Grime JP (2006). Trait convergence and trait divergence in herbaceous plant communities: mechanisms and consequences. Journal of Vegetation Science 17 (2): 255-260. - doi: 10.1111/j. 1654-1103.2006.tbo2444.x

Grime JP, Pierce S (2012). The evolutionary strategies that shape ecosystems. John Wiley and Sons Ltd, Chichester, UK, pp. 264. [online] URL: http://books.google.com/books?id=kDnG U-elg3kC

Guo WY, Van Kleunen M, Winter M, Weigelt P, Stein A, Pierce S, Pergl J, Moser D, Maurel N, Lenzner B, Kreft H, Essl F, Dawson W, Pyšek P (2018). The role of adaptive strategies in plant naturalization. Ecology Letters 21 (9): 13801389. - doi: 10.1111/ele.13104

Kattge J, Bönisch G, Díaz S, Lavorel S, Prentice IC, Leadley P, Tautenhahn S, Werner GDA, et al. (2020). TRY plant trait database-enhanced coverage and open access. Global Change Biology 26 (1): 119-188. - doi: 10.1111/gcb.14904

Kleinbauer I, Dullinger S, Peterseil J, EssI F (2010). Climate change might drive the invasive tree Robinia pseudacacia into nature reserves and endangered habitats. Biological Conservation 143 (2): 382-39o. - doi: 10.1016/j.biocon.20 09.10 .024

Kunstler G, Falster D, Coomes DA, Hui F, Kooyman RM, Laughlin DC, Poorter L, Vanderwel $M$, Vieilledent G, Wright SJ, Aiba M, Baraloto C, Caspersen J, Cornelissen JHC, Gourlet-Fleury S, Hanewinkel M, Herault B, Kattge J, Kurokaw H,
Onoda Y, Peñuelas J, Poorter H, Uriarte $M$, Richardson S, Ruiz-Benito P, Sun IF, Ståhl G, Swenson NG, Thompson J, Westerlund B, Wirth C, Zavala MA, Zeng H, Zimmerman JK, Zimmermann NE, Westoby M (2016). Plant functional traits have globally consistent effects on competition. Nature 529 (7585): 204-207. - doi: 10.10 38/nature 16476

Leuschner C, Ellenberg H (2017). Ecology of central European forests: vegetation ecology of Central Europe. Springer, Berlin, Germany, vol. 1, pp. 971.

Leuschner C, Meier IC (2018). The ecology of Central European tree species: trait spectra, functional trade-offs, and ecological classification of adult trees. Perspectives in Plant Ecology, Evolution and Systematics 33: 89-103. - doi: 10.1016/j.ppees.2018.05.003

Macedo JA, Alves P, Lomba Vicente J, Henriques $\mathrm{R}$, Granja $\mathrm{H}$, Honrado J (2010). On the interest of plant functional classifications to study community level effects of increased disturbance on coastal dune vegetation. Acta Botanica Gallica 157 (2): 305-315. - doi: 10.1080/12538078.20 10.10516208

Mucina L, Bültmann H, Dieren K, Theurillat JP, Raus T, Carni A, Sumberová KI, Willner W, Dengler J, Gavilán García R, Chytry M, Hájek M, Di Pietro R, lakushenko D, Pallas J, Daniëls FJA, Bergmeier E, Santos Guerra A, Ermakov N, Valachovič M, Schaminee JHJ, Lysenko T, Didukh YP, Pignatti S, Rodwell JS, Capelo J, Weber HE, Solomeshch A, Dimopoulos P, Aguiar C, Hennekens SM, Tichy L (2016). Vegetation of Europe: hierarchical floristic classification system of vascular plant, bryophyte, lichen, and algal communities. Applied Vegetation Science 19 (1): 3-264. - doi: 10.1111/avsc.12257

Pierce S, Brusa G, Vagge I, Cerabolini BEL (2013). Allocating CSR plant functional types: the use of leaf economics and size traits to classify woody and herbaceous vascular plants. Functional Ecology 27 (4): 1002-1010. - doi: 10.1111/136 5-2435.12095

Pierce S, Negreiros D, Cerabolini BEL, Kattge J, Díaz S, Kleyer M, Shipley B, Wright SJ, Soudzilovskaia NA, Onipchenko VG, Van Bodegom PM, Frenette-Dussault C, Weiher E, Pinho BX, Cornelissen JHC, Grime JP, Thompson K, Hunt R, Wilson PJ, Buffa G, Nyakunga OC, Reich PB, Caccianiga $M$, Mangili F, Ceriani RM, Luzzaro A, Brusa G, Siefert A, Barbosa NPU, Chapin III FS, Cornwell WK, Fang J, Fernandes JW, Garnier E, Le Stradic S, Peñuelas J, Melo FPL, Slaviero A, Tabarelli M, Tampucci D (2017). A global method for calculating plant CSR ecological strategies applied across biomes world-wide. Functional Ecology 31 (2): 444-457. - doi: 10.1111/13652435.12722

Pignatti S, Oberdorfer E, Schaminée JHJ, Westhoff $\vee(1995)$. On the concept of vegetation class in phytosociology. Journal of Vegetation Science 6 (1): 143-152. - doi: 10.2307/3236265

Pignatti S, Guarino R, La Rosa M (2017). Flora d'italia [Italian Flora] ( $2^{\text {nd }}$ edn). Edagricole, Bologna, Italy, pp. 1178. [in Italian]

Poldini L, Sburlino G, Buffa G, Vidali M (2011). Correlations among biodiversity, biomass and other plant community parameters using the phytosociological approach: a case study from the south-eastern Alps. Plant Biosystems 145
(1): 131-140. - doi: 10.1080/11263504.2010.547673 Pyšek P, Pergl J, EssI F, Lenzner B, Dawson W, Kreft $H$, Weigelt $P$, Winter $M$, Kartesz J, Nishino M, Antonova LA, Barcelona JF, Cabezas FJ, Cárdenas D, Cárdenas-Toro J, CastaA, Chacón E, Chatelain C, Dullinger S, Ebel AL, Figueiredo E, Fuentes N, Genovesi P, Groom QJ, Henderson L, Inderjit Kupriyanov A, Masciadri S, Maurel N, Meerman J, Morozov O, Moser D, Nickrent D, Nowak PM, Pagad S, Patzelt A, Pelser PB, Seebens H, Shu W, Thomas J, Velayos M, Weber E, Wieringa JJ, Baptiste MP, Van Kleunen M (2017). Naturalized alien flora of the world. Preslia 89 (3): 203-274. - doi: 10.23855/preslia. 2017.203

Pyšek P, Sádlo J, Mandák B, Jarošík V (2003). Czech alien flora and the historical pattern of its formation: what came first to Central Europe? Oecologia 135 (1): 122-130. - doi: 10.1007/ s00442-002-1170-7

R Core Team (2020). R: a language and environment for statistical computing. R Foundation for Statistical Computing, Vienna, Austria. [online] URL: http://www.r-project.org/

Ricotta C, Acosta AT, Caccianiga M, Cerabolini BEL, Godefroid S, Carboni M (2020). From abundance-based to functional-based indicator species. Ecological Indicators 118: 106761. - doi: 10.1016/j.ecolind.2020.106761

Rodwell JS, Evans D, Schaminée JH (2018). Phytosociological relationships in European Union policy-related habitat classifications. Rendiconti Lincei - Scienze Fisiche e Naturali 29 (2): 237249. - doi: 10.1007/s12210-018-0690-y

Rueda M, Godoy O, Hawkins BA (2018). Trait syndromes among North American trees are evolutionarily conserved and show adaptive value over broad geographic scales. Ecography 41 (3): 540-550. - doi: 10.1111/ecog.03008

Silva MAM, Pinto ADVF, Do Nascimento LM, Lins-e-Silva ACB, De Lima ALA, Rodal MJN (2015). Does the plant economics spectrum change with secondary succession in the forest? Trees 29 (5): 1521-1531. - doi: 10.1007/s0046 8-015-1232-1

Smith TM, Shugart HH, Woodward FI, Burton PJ (1992). Plant functional types. In: "Vegetation Dynamics and Global Change" (Solomon AM, Shugart HH eds). Chapman and Hall, New York, USA, pp. 272-292. - doi: 10.1007/978-1-4615-28166_14

Thonicke K, Billing M, Von Bloh W, Sakschewski B, Niinemets U, Peñuelas J, Cornelissen JHC, Onoda Y, Van Bodegom P, Schaepman ME, Schneider FD, Walz A (2020). Simulating functional diversity of European natural forests along climatic gradients. Journal of Biogeography 47 (5): 1069-1085. - doi: 10.1111/jbi.13809 Van Der Maarel E, Franklin J (2012). Vegetation ecology ( $2^{\text {nd }}$ edn). John Wiley and Sons Ltd, Chichester, UK, pp. 556. [online] URL: http:// books.google.com/books?id=bY_VpioznAAC Viciani D, Vidali M, Gigante D, Bolpagni R, Villani $M$, Acosta ATR, Adorni M, Aleffi M, Allegrezza $M$, Angiolini $C$, Assini $S$, Bagella $S$, Bonari $G$, Bovio M, Bracco F, Brundu G, Buffa G, Caccianiga $\mathrm{M}$, Carnevali $\mathrm{L}$, Ceschin $\mathrm{S}$, Ciaschetti $\mathrm{G}, \mathrm{Co}-$ goni A, Di Cecco V, Foggi B, Frattaroli AR, Genovesi P, Gentili R, Lazzaro L, Lonati $M$, Lucchese F, Mainetti A, Mariotti M, Minissale P, Paura B, Pellizzari M, Perrino EV, Pirone G, Poggio L, Pol- 
dini L, Poponessi S, Prisco I, Prosser F, Puglisi M, Rosati L, Selvaggi A, Sottovia L, Spampinato G, Stanisci A, Stinca A, Venanzoni R, Lastrucci L (2020). A first checklist of the alien-dominated vegetation in Italy. Plant Sociology 57 (1): 29-54. - doi: 10.3897/pls2020571/04

Westoby M, Leishman MR, Lord JM (1995). On misinterpreting the phylogenetic correction. Journal of Ecology 83 (3): 531-534. - doi: 10.230 7/2261605

Wright IJ, Reich PB, Westoby M, Ackerly DD, Baruch Z, Bongers F, Cavender-Bares J, Chapin T, Cornelissen JHC, Diemer M, Flexas J, Garnier E, Groom PK, Gulias J, Hikosaka K, Lamont BB, Lee T, Lee W, Lusk C, Midgley JJ, Navas ML, Niinemets $\mathrm{U}$, Oleksyn J, Osada N, Poorter H, Poot P, Prior L, Pyankov VI, Roumet C, Thomas SC, Tjoelker MG, Veneklaas MJ, Villar R (2004). The worldwide leaf economics spectrum. Nature 428 (6985): 821-827. - doi: 10.1038/nature02403 Zanzottera $M$, Dalle Fratte $M$, Caccianiga $M$, Pierce S, Cerabolini BEL (2020). Communitylevel variation in plant functional traits and ecological strategies shapes habitat structure along succession gradients in alpine environment. Community Ecology 21: 55-65. - doi: 10.1007/s42974-020-00012-9

\section{Supplementary Material}

Fig. S1 - Sampling sites distribution.

Fig. S2 - Additional documentation to PCA.

Fig. S3 - Hierarchical clustering on PCA.
Fig. S4 - Mean values of classes along the first two principal components.

Fig. S5 - Additional documentation to analysis of CSR scores.

Fig. S6 - Additional documentation to analysis of neophytes.

Tab. S1 - Sampling sites properties.

Tab. S2 - Distribution among classes.

Tab. S3 - The original dataset.

Link: Zanzottera_3730@supplo01.pdf 